\title{
Econometric Evaluation of Micro Factors of Seasonality on Revenues, Price, Sales and Farmers Work-Occupation: Case of Apple And Tomato on the Regions of Prizren, Lushnja, and Korça
}

PhD. Eriona Deda

Agricultural University of Tirana, Faculty of Economics and Agribusiness

Doi:10.5901/mjss.2017.v8n3p351

\begin{abstract}
The aim of this study is to analyze the importance of effects and impact of seasonal fluctuations on income of farmers, workoccupation in farm and sales on apples activity for areas of Korça and Prizren, and in tomatos activities for areas Lushnja and Prizren. Lushnja area is one of the most popular areas of Albania on the quality of vegetable production. Seasonal effects that influence on the apples production in areas of Korça and Prizren and tomatos in areas of Lushnja and Prizren. Some seasonal effects comes as a result of weather conditions, pests and diseases, and are more expressed in those economic phenomenon such us: the volatility of price over year, to farmers income and to farmers work-occupation over a year. We also can say that the production of apples and tomatos in our country includes more intensive activities of production that require large investments. Their production cost turns out to be higher for manufacturers, but, while also enabling high levels of profit. Our estimates are based on data obtained from surveys, for 300 farmers, to make our evaluations we build some econometric models. In this paper we have used the model of seasonal indexes, where seasonal variation can be measured in terms of an index called the seasonal index. We have used these methods: seasonal indexes standard deviations, and econometric modeling. Also we have defined indicators and values of the variations coefficient. The variations coefficient is a relative indicator which expresses the ratio between to standard deviation size and arithmetic average of mass phenomenon.
\end{abstract}

Keywords: seasonal differences, seasonal effects, seasonal fluctuations, seasonal index,seasonal variation

\section{Introduction}

Through this paper will assess the impact of seasonal effects or seasonal fluctuation to income of farmers of fruits and vegetables, it would be very important for farmers to make predictions regarding the production and sales,

Our problem in this research is precisely to evaluate and recognize these effects on economic phenomena such as income, prices, work-occupation, sales of farmers in activity of apples and tomatos.

Knowing them can be part of an overall assessment to efforts and governmental policy for subsidize the farmers to develop agro-economy

\section{Literature}

Through the literature review we aim to explain meaning of seasonal effects.

It is well known fact that many economic series exhibit seasonal effects. This is because they have seasonal components that is repeated in a certain frequency. (Eg every three months in the case of seasonal components, or annually in the case of cyclic components.)

The definition of seasonal factors:

Is each seasonal factors which has impact in an economic phenomenon and it repeated regularly every quarter or every year no matter what is the cause of this effect, climate, traditions, tastes and preferences of consumers.

In our paper we addressed the impact of seasonal effects to farmers income, work-occupation and sales of apples and tomatos based on quarterly data.

Based on this definition should not relied on a specific model for seasonal adjustment, because it can 't show reality, also should not rely neither on a particular method. 
${ }^{1}$ The first overall seasonal adjustment methodology was created by Macauly (1930). This approach includes the X11-ARIMA method.

Two major developments came during the early 1950s.

The first was the introduction of exponential techniques for smoothing seasonal components, which have simplified the tedious calculations.

The second development was the provision of computational methods, which provide calculations that can be performed in a few seconds, That previously had took a number of days to perform these calculations.

Introduction to a volume for treatment of inflation.

Seasonality in the inflation measures

${ }^{2}$ The X11 procedure developed by Dagum (1980), the statistical office of Canada. including: Model of Seasonal Adjustment of - sales X-11 census, Seasonal adjustment program, and Implementation of the X-11.

Dagum had developed a model variant X-11 Arima, unlike the variants X-11-Arima who had been developed by his predecessors, using ARIMA model to make seasonal adjustment on a original time series, monthly or quarterly.

By introducing new versions of the X11-ARIMA / 88 and X11-ARIMA / 2000. These are semi-parametric models. Implementation of the X-11-ARIMA Seasonal Adjustment Method in an original time series monthly or quarterly, is forecast to last the original time series.

Extension of time series improves estimation of seasonal factors, in this series new data become available.

X11 procedure involves assessment of the seasonal component using the moving average to make seasonal smoothing. This type of analysis gives a diagnosis to determine the seasonal suitability in an economic series

${ }^{3}$ Bert M. Balk, W. Erwin Diewert and Alice O. Nakamura

Although the problem has already signaled in 1920, this paper is mainly based on the measurement of price level changes in seasonal products depending on seasonality.

In this paper, in any case, the data of time series, monthly or quarterly, should be smoothed through its methods for seasonal adjustment, using methods that are the culmination of an extensive literature on the subject of seasonal adjustment of economic time series.

This literature in turn is a subsidiary of an even larger literature that demonstrates how can deal directly price indices, without assumption that unstable prices can be measured for all products in all seasons.

${ }^{4}$ Statistics Denmark, January 2005

Peter Linde

The purpose of this paper is to provide an overview of the concept of seasonal components in a time series. The paper provides a comprehensive introduction in the subject that intend use of statistical methods Included in the seasonal adjustment.

Furthermore, this paper describes the X-12 ARIMA program ; that is the program for Seasonal Adjustment in time series that is used in the Danish statistics.

Some methods to reduce seasonal component from a time series are:

Moving averages, in themselves have a smoothing effect on seasonal variations.

Also use of the X-12-ARIMA seasonal adjustment program in a time series.

This program makes seasonal adjustment in a time series using an additional model.

${ }^{5}$ Experiences With Indirect Seasonal Adjustment Kathleen M. McDonald-Johnson, Catherine C. Harvill Hood, Roxanne Feldpausch U.S. Census Bureau, HENDYPLAN Luxembourg, U.S. Census Bureau

In their paper they have focused on the use of appropriate programs for regulation of seasonal fluctuations in time series using the seasonal adjustment programs to an individual time series and then to combining them using special software

X-12-ARIMA and X-11-Arima, that have the ability to combine the seasonally adjusted series that provide indirect diagnostics of seasonality.

\footnotetext{
${ }^{1}$ Erika Foldesi , Peter Bauer, Beata Horvath \&Beta Urr , (2007), Seasonal adjustment methods and practices, 131,7:[Online] Available: http://ec.europa.eu/eurostat/documents/64157/4374310/29-SEASONAL-ADJUSTMENT-METHODS-PRACTICES-2007.pdf/6628a64e2160-4e6f-a34a-499d0f5cdcfe (July ,2007)

${ }^{2}$ Dagum ,Estela Bee, (1980), The X11 Arima, [Online] Avaiable :https://www.census.gov/ts/papers/1980X11ARIMAManual.pdf (1980).

${ }^{3}$ W. Erwin Diewert, Bert M. Balk, Dennis Fixler, Kevin J. Fox, \& Alice O. Nakamura, (2009), Price and productivity measurement, [Online] Available::http://www.indexmeasures.com/Vol2,\%20Seasonality\%2009Z,10,18.pdf (October 18, 2009)

${ }_{4}^{4}$ Peter Linde, Statistics Denmark, (2005), [Online] Avaiable:file:///C:/Users/User/Downloads/seasonal_001-pdf\%20(1).pdf (January,2005)

${ }^{5}$ Kathleen M. McDonald-Johnson, Catherine C. Harvill Hood, Roxane Feldpausch,\& U.S. Census Bureau, (2005),Experiences With Indirect Seasonal Adjustment, [Online] Available:http://www.catherinechhood.net/papers/jsm2005kmj.pdf (2005)
} 


\section{Research Methods}

The methods we have used are statistical and econometric.

While through econometric models we show the connection between variables.

We have used the seasonal index and coefficient of variance which expresses the seasonal effects or seasonality in economic phenomena under this study.

Working methodology is based on collection of primary data and the secondary data.

We have used seasonal indexes standard deviations, and econometric modeling.

The seasonal index is an average that can be used to compare a current observations about what would happen if there would be no seasonal variations.

An index value is attached to each time series period within a year. The variation is expressed through indicators that reflect the level of deviations from the average data size of phenomenon analyzed.

The variation indicators used to indicate phenomenon of the distribution analyzed.

Coefficient of variation is a relative indicator which expresses the ratio between size of the standard deviation and arithmetic average of phenomenon.

The smaller is the ratio of the variation more homogeneous is the data quantity of the phenomenon. Namely the impact of external factors, is in min and the opposite.

\subsection{Purpose}

Purpose of this paper is to appreciate significance of the seasonal effects model to these economic phenomena, on income, work-occupation, and sales of products received in the study by quarters.

\subsection{The research questions}

In which quarterly are more expressed the seasonal effects according to the study products in income, work-occupation of farmers according to quarterly data, or in sales.

\subsection{The data and choice}

With regard to the primary data source, these data are obtained through surveys.

We have surveyed a total of 300 farmers who exercise their activity in apples and tomatos..

from these are surveyed a total of 100 farmers who operate in the activity of apples for Korça area and 100 farmers who exercise their activity in tomatos for Lushnja area.

our study is based on quarterly data.

The information is accumulated through interviews via questionnaires.

Secondary data sources are: The literature from the statistics and econometrics module, econometric eviews7 program.

Variables taken in the study are: Revenues of farmers in apples and tomatos, price of apples and tomatos according to areas and quarterly data, work-occupation of farmers in activity of apples and tomatos according to areas and quarterly data. 


\section{Analysis Result}

\subsection{The importance of econometric model on seasonality related to apples income for Korça area}

${ }^{6}$ Dependent Variable: INCOME ,Coefficient of Variance

Method: Least Squares

Sample: 1100

Included observations: 100

\begin{tabular}{lllll}
\hline \hline Variable & Coefficient & Std. Error & t-Statistic & Prob. \\
\hline \hline C & 215.1145 & 18.26769 & 11.77568 & 0.0000 \\
FARM SIZE & 0.278243 & 1.615955 & 0.172185 & 0.8637 \\
EDUCATION & -8.756407 & 4.889216 & -1.790963 & 0.0766 \\
IRRIG & -0.836154 & 1.397002 & -0.598535 & 0.5509 \\
AGE & -0.165293 & 0.266137 & -0.621082 & 0.5361 \\
NUM.OF PARCEL & -7.581645 & 6.199151 & -1.223013 & 0.2244 \\
NUM. OF EMPLOYEES & 0.694174 & 1.451144 & 0.478363 & 0.6335 \\
\hline \hline R-squared & 0.083713 & Mean dependent var & 173.3707 \\
Adjusted R-squared & 0.024598 & S.D. dependent var & 21.10846 \\
S.E. of regression & 20.84723 & Akaike info criterion & 8.979748 \\
Sum squared resid & 40418.44 & Schwarz criterion & 9.162110 \\
Log likelihood & -441.9874 & F-statistic & 1.416104 \\
Durbin-Watson stat & 1.663883 & Prob(F-statistic) & 0.216736 \\
\hline \hline
\end{tabular}

The coefficient of variance or seasonal index which expresses the seasonal effects or seasonality in this case for income does not depend by any factor, since the bulk of the relevant variables coefficients have negative value.

Regarding the importance of the seasonal effects related to income of apples to Korca region, we say that entirely effect of seasonal factors is important on income of apples with a high coefficient of determination of $83 \%$.

\subsection{The importance of econometric model on seasonality related to income of tomatos for Lushnja area}

Dependent Variable: Income CV

Method: 7 Least Squares

Sample: 101200

Included observations: 100

\begin{tabular}{lllll}
\hline \hline Variable & Coefficient & Std. Error & t-Statistic & Prob. \\
\hline \hline C & 122.8770 & 0.801250 & 153.3565 & 0.0000 \\
FARM SIZE & -0.139983 & 0.033116 & -4.226998 & 0.0001 \\
\hline \hline R-squared & 0.154206 & Mean dependent var & 121.0947 \\
Adjusted R-squared & 0.145576 & S.D. dependent var & 7.371009 \\
S.E. of regression & 6.813398 & Akaike info criterion & 6.695456 \\
Sum squared resid & 4549.394 & Schwarz criterion & 6.747559 \\
Log likelihood & -332.7728 & F-statistic & 17.86751 \\
Durbin-Watson stat & 1.747624 & Prob(F-statistic) & 0.000053 \\
\hline \hline
\end{tabular}

Income ${ }^{8} \mathrm{CV}=122.877002-0.1399828753^{*}$ FARM SIZE

The coefficient of variance or seasonal index which expresses the seasonal effects or seasonality in this case for farm income in activity of tomato for Lushnja region. We say that with increasing farm size decreases coefficient of variance.

The Variance coefficient is depended by farm size.

Regarding the impact of seasonality in relation to income of tomato for Lushnja region we say that entirely

\footnotetext{
${ }^{6}$ Eview 3 Programme

7 Osmani, M. (2010). The multiple model of regression (pp:49-54). Tirana, Albania, 2010

8 Osmani, M. (2004). Coefficient of variation (pp.99-101). Tirana, Albania: GEER, 2004.
} 
effects of seasonal factors in relation on farm size is'nt relevant to income of tomato with lower coefficient of determination $15 \%$.

\subsection{The importance of econometric model on seasonality related to income of tomatos for Prizren area}

Dependent Variable: Income CV

Method: Least Squares

Sample: 201270

Included observations: 70

\begin{tabular}{lllll}
\hline \hline Variable & Coefficient & Std. Error & t-Statistic & Prob. \\
\hline \hline C & 82.82962 & 0.871007 & 95.09639 & 0.0000 \\
FARM SIZE & 0.083065 & 0.054386 & 1.527307 & 0.1313 \\
\hline \hline 9R-squared & 0.033166 & Mean dependent var & 83.90234 \\
Adjusted R-squared & 0.018948 & S.D. dependent var & 4.351170 \\
S.E. of regression & 4.309750 & Akaike info criterion & 5.787792 \\
Sum squared resid & 1263.028 & Schwarz criterion & 5.852035 \\
Log likelihood & -200.5727 & F-statistic & 2.332668 \\
Durbin-Watson stat & 1.955377 & Prob(F-statistic) & 0.131323 \\
\hline \hline
\end{tabular}

The coefficient of variance or seasonal index which expresses seasonal effects or seasonality in this case for farm income in tomatos for Prizren region. We say that coefficient of variance not depend by size of farm.

Regarding the importance of seasonality impact in relation to income of tomatos for Prizren region we say that entirely effect of seasonal factors in relation on farm size is 'nt relevant to income of tomatos with lower coefficient of determination $3 \%$.

\subsection{The importance of econometric model on seasonality related to price of apples for Korça region.}

Dependent Variable: PRICE CV

Method: Least Squares

Sample: 1100

Included observations: 100

\begin{tabular}{lllll}
\hline \hline Variable & Coefficient & Std. Error & t-Statistic & Prob. \\
\hline \hline C & 201.2848 & 48.58109 & 4.143274 & 0.0001 \\
FARM SIZE & -4.784201 & 4.297471 & -1.113259 & 0.2685 \\
EDUCATION & -5.795349 & 13.00238 & -0.445714 & 0.6568 \\
IRRIG & 5.185368 & 3.715187 & 1.395722 & 0.1661 \\
AGE & -0.087094 & 0.707764 & -0.123055 & 0.9023 \\
NUM. OF PARCELS & 4.947400 & 16.48602 & 0.300097 & 0.7648 \\
NUM.OF MPLOYEES & -12.70425 & 3.859172 & -3.291963 & 0.0014 \\
\hline \hline R-squared & 0.145206 & Mean dependent var & 134.9820 \\
Adjusted R-squared & 0.090058 & S.D. dependent var & 58.11992 \\
S.E. of regression & 55.44112 & Akaike info criterion & 10.93595 \\
Sum squared resid & 285855.7 & Schwarz criterion & 11.11831 \\
Log likelihood & -539.7975 & F-statistic & 2.633015 \\
Durbin-Watson stat & 1.142018 & Prob(F-statistic) & 0.021060 \\
\hline \hline
\end{tabular}

The coefficient of variance or seasonal index which expresses seasonal effects or seasonality in this case for farm price in apples for Korça region. We say that coefficient of variance depends by only one factor, number of employees.

Regarding the importance of seasonality impact in relation to price of apples for Korça region we say that entirely effect of seasonal factors in relation on farm size is ' nt relevant on apples price with lower coefficient of determination $14 \%$.

${ }^{9}$ Osmani, M. (2010). Calculation of the general correlation coefficient (pp. 52-54). Tirana, Albania. (2010) 


\subsection{The importance of econometric model on seasonality related to price of tomatos for Lushnja region.}

Dependent Variable: PRICE CV

Method: Least Squares

Sample: 101200

Included observations: 100

\begin{tabular}{lllll}
\hline \hline Variable & Coefficient & Std. Error & t-Statistic & Prob. \\
\hline \hline C & 57.08886 & 5.161947 & 11.05956 & 0.0000 \\
FARM SIZE & 0.146241 & 1.491574 & 0.098045 & 0.9221 \\
EDUCATION & 0.607040 & 1.583787 & 0.383284 & 0.7024 \\
IRRIG & 0.267362 & 1.447658 & 0.184686 & 0.8539 \\
AGE & -0.026473 & 0.106015 & -0.249707 & 0.8034 \\
NUM. OF PARCEL & -1.247592 & 1.096671 & -1.137618 & 0.2582 \\
NUM. OF EMPLOYEES & -0.770094 & 0.508107 & -1.515612 & 0.1330 \\
\hline \hline R-squared & 0.041486 & Mean dependent var & 55.02804 \\
Adjusted R-squared & -0.020354 & S.D. dependent var & 8.431321 \\
S.E. of regression & 8.516693 & Akaike info criterion & 7.189363 \\
Sum squared resid & 6745.667 & Schwarz criterion & 7.371724 \\
Log likelihood & -352.4681 & F-statistic & 0.670864 \\
Durbin-Watson stat & 1.922154 & Prob(F-statistic) & 0.673380 \\
\hline \hline
\end{tabular}

The coefficient of variance or seasonal index which expresses seasonal effects or seasonality in this case for price of tomatos for Lushnja region. We say that coefficient of variance not depends by any factor.

Regarding the importance of seasonality impact in relation to price of tomatos for Lushnja region we say that entirely effect of seasonal factors in relation on farm size is'nt relevant on tomatos price with lower coefficient of determination $4 \%$.

\subsection{The importance of econometric model on seasonality related to price of tomatos for Prizren region.}

Dependent Variable: Price CV

Method: Least Squares

Sample: 201270

Included observations: 70

\begin{tabular}{lllll}
\hline \hline Variable & Coefficient & Std. Error & t-Statistic & Prob. \\
\hline \hline C & 81.68034 & 4.987249 & 16.37783 & 0.0000 \\
FARM SIZE & -2.683757 & 6.946967 & -0.386321 & 0.7006 \\
EDU & -0.021897 & 0.185857 & -0.117814 & 0.9066 \\
IRRIG & 2.669900 & 6.938353 & 0.384803 & 0.7017 \\
AGE & -0.031681 & 0.130777 & -0.242253 & 0.8094 \\
NUM. OF PARCEL & 0.586817 & 1.400270 & 0.419074 & 0.6766 \\
NUM. OF EMPLOYEES & -0.259371 & 0.746879 & -0.347273 & 0.7295 \\
\hline \hline R-squared & 0.018662 & Mean dependent var & 79.61901 \\
Adjusted R-squared & -0.074799 & S.D. dependent var & 6.591398 \\
S.E. of regression & 6.833468 & Akaike info criterion & 6.776181 \\
Sum squared resid & 2941.866 & Schwarz criterion & 7.001031 \\
Log likelihood & -230.1663 & F-statistic & 0.199675 \\
Durbin-Watson stat & 2.167580 & Prob(F-statistic) & 0.975681 \\
\hline \hline
\end{tabular}

The coefficient of variance or seasonal index which expresses seasonal effects or seasonality in this case of tomatos prices for Prizren region. In this case we say that coefficient of variance not depends by any factor.

Regarding the importance of seasonality impact in relation to price of tomatos for Prizren region can say that entirely effect of seasonal factors on price of tomatos is not is 'nt relevant with lower coefficient of determination $2 \%$. 


\subsection{The importance of econometric model on seasonality related to work-ocupation on apple activity for Prizren region}

Dependent Variable: Work-Occupation, Coefficient of Variance

Method: Least Squares

Sample: 271300

Included observations: 30

\begin{tabular}{lllll}
\hline \hline Variable & Coefficient & Std. Error & t-Statistic & Prob. \\
\hline \hline C & 26.05399 & 2.363921 & 11.02151 & 0.0000 \\
FARM SIZE & 0.097805 & 0.227433 & 0.430036 & 0.6705 \\
\hline \hline R-squared & 0.006561 & Mean dependent var & 26.95053 \\
Adjusted R-squared & -0.028919 & S.D. dependent var & 6.017002 \\
S.E. of regression & 6.103383 & Akaike info criterion & 6.519904 \\
Sum squared resid & 1043.036 & Schwarz criterion & 6.613317 \\
Log likelihood & -95.79856 & F-statistic & 0.184931 \\
Durbin-Watson stat & 2.424707 & Prob(F-statistic) & 0.670461 \\
\hline \hline
\end{tabular}

The coefficient of variance or seasonal index which expresses seasonal effects or seasonality in this case for workocupation on apples for Prizren region .

In this case we say that coefficient of variance not depends by any factor.

Regarding the importance of seasonality impact in relation to price of tomatos for Prizren region can say that entirely effect of seasonal factors on the price of tomatos is 'nt relevant with lower coefficient of determination.

\subsection{The importance of econometric model on seasonality related to work-ocupation on apple activity for Korça region}

Dependent Variable: Coefficient of Variance

Method: Least Squares

Sample: 1100

Included observations: 100

\begin{tabular}{lllll}
\hline \hline Variable & Coefficient & Std. Error & t-Statistic & Prob. \\
\hline \hline C & 36.52200 & 5.675927 & 6.434543 & 0.0000 \\
FARM SIZE & 0.234763 & 0.502091 & 0.467570 & 0.6412 \\
EDUCATION & -1.377327 & 1.519121 & -0.906660 & 0.3669 \\
IRRIG & -0.308938 & 0.434060 & -0.711740 & 0.4784 \\
AGE & -0.127822 & 0.082691 & -1.545783 & 0.1256 \\
NUM. OF EMPLOYEES & 0.276803 & 0.450883 & 0.613914 & 0.5408 \\
NUM. OF PARCEL & -1.764987 & 1.926129 & -0.916339 & 0.3619 \\
\hline \hline R-squared & 0.054249 & Mean dependent var & 25.39648 \\
Adjusted R-squared & -0.006767 & S.D. dependent var & 6.455606 \\
S.E. of regression & 6.477412 & Akaike info criterion & 6.641948 \\
Sum squared resid & 3901.988 & Schwarz criterion & 6.824310 \\
Log likelihood & -325.0974 & F-statistic & 0.889096 \\
Durbin-Watson stat & 1.265129 & Prob(F-statistic) & 0.506268 \\
\hline \hline
\end{tabular}

The coefficient of variance or seasonal index which expresses seasonal effects or seasonality in this case for workoccupation of farmers on apples for Korça region.

In this case we say that coefficient of variance not depends by any factor.

Regarding the importance of seasonality impact can say that entirely effect of seasonal factors in tomatos is 'nt relevant on work-occupation of farmers in apples activity with lower coefficient of determination $5 \%$. 
4.9 The importance of econometric model on seasonality related to work-ocupation on tomatos activity for Lushnja region

Dependent Variable: Work-occupation ,Coefficient of Variance

Method: Least Squares

Sample: 101200

Included observations: 100

\begin{tabular}{|c|c|c|c|c|}
\hline Variable & Coefficient & Std. Error & t-Statistic & Prob. \\
\hline $\begin{array}{l}\text { C } \\
\text { FARM SIZE } \\
\text { AGE }\end{array}$ & $\begin{array}{l}59.76286 \\
0.263066 \\
-0.662529 \\
\end{array}$ & $\begin{array}{l}11.81674 \\
0.115601 \\
0.277748 \\
\end{array}$ & $\begin{array}{l}5.057473 \\
2.275632 \\
-2.385363 \\
\end{array}$ & $\begin{array}{l}0.0000 \\
0.0251 \\
0.0190 \\
\end{array}$ \\
\hline $\begin{array}{l}\text { R-squared } \\
\text { Adjusted R-squared } \\
\text { S.E. of regression } \\
\text { Sum squared resid } \\
\text { Log likelihood } \\
\text { Durbin-Watson stat }\end{array}$ & $\begin{array}{l}0.081459 \\
0.062520 \\
22.94052 \\
51047.93 \\
-453.6614 \\
0.437870\end{array}$ & $\begin{array}{l}\text { Mean de } \\
\text { S.D. de } \\
\text { Akaike i } \\
\text { Schwarz } \\
\text { F-statist } \\
\text { Prob(F- }\end{array}$ & $\begin{array}{l}\text { nt var } \\
\text { t var } \\
\text { erion } \\
\text { on }\end{array}$ & $\begin{array}{l}34.74274 \\
23.69312 \\
9.133227 \\
9.211382 \\
4.301124 \\
0.016229\end{array}$ \\
\hline
\end{tabular}

Work-occupation, $C V=59.7628636+0.2630663496^{\star}$ FARM SIZE $-0.6625288688^{\star}$ AGE

The coefficient of variance or ${ }^{10}$ seasonal index which expresses seasonal effects or seasonality in this case for work-occupation of farmers on tomatos activity for Lushnja region.

In this case we say that coefficient of variance depend by only two factor, farm size and farmers age.

Regarding the importance of impact of seasonality can say that entirely effect of seasonal factors is 'nt relevant on work-occupation of farmers in tomatos for Lushnja region with lower coefficient of determination $8 \%$.

4.10 The importance of econometric model on seasonality related to tomatos sales for Lushnja region.

\begin{tabular}{|c|c|c|c|c|}
\hline Variable & Coefficient & Std. Error & t-Statistic & Prob. \\
\hline $\begin{array}{l}\text { C } \\
\text { FARM SIZE }\end{array}$ & $\begin{array}{l}44.59990 \\
0.084249 \\
\end{array}$ & $\begin{array}{l}0.919137 \\
0.037989 \\
\end{array}$ & $\begin{array}{l}48.52366 \\
2.217743 \\
\end{array}$ & $\begin{array}{l}0.0000 \\
0.0289 \\
\end{array}$ \\
\hline $\begin{array}{l}\text { R-squared } \\
\text { Adjusted R-squared } \\
\text { S.E. of regression } \\
\text { Sum squared resid } \\
\text { Log likelihood } \\
\text { Durbin-Watson stat }\end{array}$ & $\begin{array}{l}0.047789 \\
0.038073 \\
7.815842 \\
5986.564 \\
-346.4990 \\
1.927640\end{array}$ & $\begin{array}{l}\text { Mean d } \\
\text { S.D. de } \\
\text { Akaike i } \\
\text { Schwar } \\
\text { F-statist } \\
\text { Prob(F- }\end{array}$ & $\begin{array}{l}\text { ht var } \\
\text { var } \\
\text { rion } \\
\text { n }\end{array}$ & $\begin{array}{l}45.67256 \\
7.969015 \\
6.969980 \\
7.022083 \\
4.918383 \\
0.028882\end{array}$ \\
\hline
\end{tabular}

\section{Sales, CV $=44.59989579+0.0842492587^{\star}$ FARM SIZE}

The coefficient of variance or seasonal index which expresses the seasonal effects or seasonality in this case for sales of farmers on tomatos for Lushnja region.

In this case we say that coefficient of variance is depended by only one factor, farm size.

Regarding the importance of impact of seasonality can say that entirely effect of seasonal factors is 'nt relevant on tomatos sales for Lushnja region with lower coefficient of determination $4 \%$.

10 Osmani.M, (2004), Evaluation of seasonal components, Seasonal Indexes (Is),(pp: 377-381), Tirana, Albania, 2004 


\subsection{The importance of econometric model on seasonality related to apples sales for Korça region.}

Dependent Variable: SALES, Coefficient of Variance

Method: Least Squares

Sample: 1100

Included observations: 100

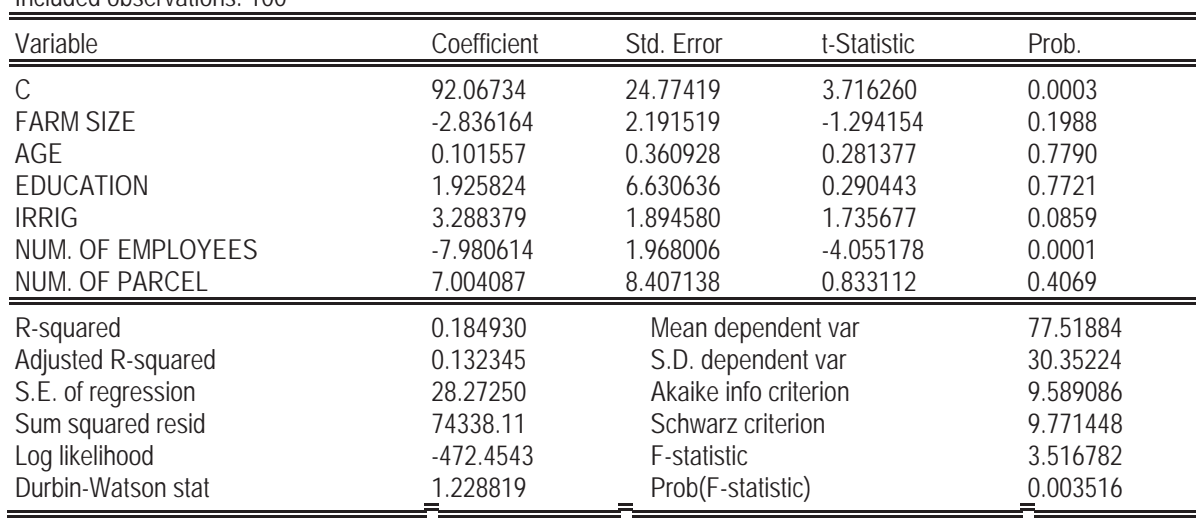

SALES, $\quad$ CV $=92.06734482-2.836163737^{\star} F A R M$ SIZE + 0.1015567156*AGE + 1.925823763*EDUCATION + 3.288378854*IRRIG - 7.98061416*NUM. OF EMPLOYEES + 7.004086736*NUM. OF PARCEL

The coefficient of variance or seasonal index which expresses seasonal effects or seasonality in this case for sales of farmers on apples for Korça region.

In this case we say that coefficient of variance depends negatively only by one factor, number of employees.

Regarding to seasonality impact can say that entirely effect of seasonal factors is'nt relevant on farmers sales in apples with lower coefficient of determination $18 \%$.

\section{Conclusions and Recommendations}

Through this paper we point out the impact of seasonal effects in these economic phenomena, mainly to income of farmers, price, work occupation and sales production in connection with apples for Korça and Prizren areas and tomatos for Lushnja and Prizren areas.

Also we defined the relationship between variables of model and significance of seasonal effect for each of products and quarters for Korça,Lushnja and Prizren areas.

Also through charts we have analyzed seasonal fluctuations in products and quarters.

Assessment of seasonal effects would be very important for farmers to make predictions about revenue, production and sales.

\section{References}

Bee, D. E., (1980). The X-II-ARIMA. [Online] Avaiable :https://www.census.gov/ts/papers/1980X11ARIMAManual.pdf (1980).

Diewert,W.E., Balk, B. M., Fixler, D., Fox, K.J.\& Nakamura,A.O. . (2009). Price and productivity measurement. [Online] Available::http://www.indexmeasures.com/Vol2,\%20Seasonality\%2009Z,10,18.pdf (October 18, 2009).

Foldesi, E., Bauer, P.,Horvath, B., \& Urr,B. (2007). Seasonal adjustment methods and practices. Budapest: European Commission Grant 10300.2005.021-2005.709, [Online] Avaiable: http://ec.europa.eu/eurostat/documents/64157/4374310/29-SEASONALADJUSTMENT-METHODS-PRACTICES-2007.pdf/6628a64e-2160-4e6f-a34a-499d0f5cdcfe.

Johnson, K,M,M., Hood, C, C, H., Feldpausch, R., \& Bureau, C. (2005). Experiences With Indirect Seasonal Adjustment. U.S: [Online] Available:http://www.catherinechhood.net/papers/jsm2005kmj.pdf (2005).

Osmani, M. (2004). Coefficient of variation (Vol. II). Tirana, Albania: GEER, 2004.

Osmani, M. (2004). Evaluation of seasonal components, Seasonal Indexes (Is) (Vol. II). Tiranë, Albania: GEER, 2004.

Osmani, M. (2010). Calculation of the general correlation coefficient (Vol. 1). Tirana, Albania.

Osmani, M. (2010). The multiple model of regression (Vol. I). Tirana, Albania.

Peter, L. (2005). Statistics Denmark,. [Online] Avaiable:file:///C:/Users/User/Downloads/seasonal_001-pdf\%20(1).pdf (January,2005). 